\title{
Firm transparency and idiosyncratic risk
}

\author{
Hui-Cheng Yu ${ }^{1} \cdot$ Mao-Feng Kao ${ }^{1 *} \cdot$ Yi-Chang Chen ${ }^{2} \cdot$ Bor-Yuan Tsai $^{3}$ \\ ${ }^{1}$ School of Accounting, Hunan University of Commerce, Hunan, China \\ ${ }^{2}$ Accounting School, Nanfang College of Sun Yat-Sen University, Guangdong Province, China \\ ${ }^{3}$ Department of Accounting Information, Aletheia University, New Taipei City, Taiwan
}

Received: 1 March 2017

Revised: 6 September 2017

Accepted: 6 September 2017

\begin{abstract}
This study focuses on whether information transparency can reduce a firm's idiosyncratic risk. We measure information transparency from an annual report on the public transparency of Chinese companies. Using a simultaneous equations approach, we find that idiosyncratic risk is reduced when a firm discloses more financial and non-financial information. Our results highlight the importance of information transfer in an emerging economy.

Keywords: information transparency; idiosyncratic risk; simultaneous equations; emerging economy

JEL Classification Codes: G14, G18, O10
\end{abstract}

\section{Introduction}

One primary purpose of information disclosure is to lower the risks facing companies. There are many different risks inherent in a company. The management has to devote itself to tackling these problems in order to protect the rights and interests of stockholders and attract prospective investors. Smithson and Simkins (2005), Gordon et al. (2009), and Hoyt and Liebenberg (2011), suggest that enterprise risk management may add corporate value. In other words, the higher the quality of information disclosure, the more precision there is in the management's decisions (Bens and Monahan, 2004), and hence the lower the risk and the higher the corporate value. Given the equal importance of research on enterprise risk and information transparency, interest in these fields has continued to grow in recent years (Lee and Lui, 2011).

Jin and Myers (2006) find that the relationship between corporate governance and risk is significantly negative. However, this relationship becomes significantly positive when they control for the effect of transparency and other variables. More specifically, if the quality of information disclosure between companies cannot be identified, then it is not possible to

\footnotetext{
* Corresponding author. E-mails: maofeng.kao@gmail.com.

Citation: Yu, H.C., Kao, M.F., Chen, Y.C., and Tsai, B.Y. (2017) Firm transparency and idiosyncratic risk, Economics and Business Letters, 6(3), 81-87.
} 
observe how good the corporate governance is. For example, in 2015 the Toshiba accounting scandal was especially shocking in the Japanese capital market. Therefore, corporate governance is important to both management and investors, and what is even more important is the information transparency because of the possible linkage between this transparency and the risk. Nevertheless, prior literature focuses mainly on the investment or finance perspectives (e.g. Botosan, 1997; Bouslah et al., 2016; Lin et al., 2014), and most of these scholars overlook the information quality that is important for related risks and do not investigate the relationship from the corporate governance perspective.

Due to the above reasons and the difficulty of directly observing a firm's information transparency, first of all the relationship between information transparency and idiosyncratic risk must be clarified, particularly for the emerging market and rapid-growing economy in China, which makes an extensive contribution to, and has a considerable impact on, the global economy (e.g. Wan (2016) indicates that more than $25 \%$ of world economic growth was attributable to the development of the Chinese economy). Accordingly, this study uses a dataset of Chinese listed companies to examine the relationship between information transparency and idiosyncratic risk. However, prior studies (e.g. Lin et al., 2014) point out that there is a possible endogeneity problem arising from the linkage between information transparency and idiosyncratic risk. Hence, this study employs a simultaneous equation to solve the possible endogeneity problem.

This study extends and complements prior literature by exploring the relationship between a firm's information transparency and the idiosyncratic risk of an emerging economy from corporate governance perspectives. The remainder of this study is structured as follows. Section 2 presents hypothesis development and methodology. Section 3 introduces data. Section 4 describes empirical results. Section 5 concludes the study.

\section{Hypothesis development and methodology}

Prior studies (e.g. Gompers et al., 2003; Cremer and Nair, 2005) document that corporate governance mechanisms affect the firm value directly. Ferreira and Laux (2007) further indicate that it is private information that affects the firm value, which is highly related to firm-specific risk. In addition, Jin and Myers (2006) suggest that corporate governance is significantly and negatively related to risk; however, after they control for the effect of information transparency and other variables, the relationship is then significantly positive. In brief, the relationship between information transparency and enterprise risk does exist to some degree.

Morck et al. (2000) point out that variation in firm-specific risk is lower in emerging markets, while firm-specific stock returns are higher in developed countries. Durnev et al. (2004) find that firm-specific risk variation is reflected in share prices that have the information content. Likewise, Jin and Myers (2006) argue that firms with lower accounting information transparency have lower firm-specific risk variation. Hughes et al. (2007) argue that in welldeveloped economies, idiosyncratic risk and asymmetric information risk are fully diversifiable. Specifically, firms can raise capital at lower costs through disclosures that reduce investors' views of systematic risk (Lambert et al., 2007).

Recently, Heinle and Verrecchia (2012) investigate idiosyncratic risk, systematic risk and firm welfare, and find that reducing idiosyncratic risk will generate countervailing effects. Lee et al. (2015) have used the t-test method to examine the relationship between information transparency and idiosyncratic risk, and they find that the idiosyncratic risk of firms violating the material information disclosure rules is higher than that of firms complying with the rules. In contrast, Lin et al. (2014) suggest that information transparency is significantly and positively correlated with idiosyncratic risk. 
Based on the above discussion, the empirical evidence of prior literature on the relationship between information transparency and idiosyncratic risk is still inconclusive. However, from corporate governance perspectives, information disclosure can reduce information asymmetry and mitigate the investors' adverse selection problem, and can also develop a basis for outsiders to oversee and regulate the activities and declarations of insiders (Bushman and Smith, 2003) and further lower the probability of idiosyncratic risk. Thus, the following hypothesis is now proposed: information transparency is negatively associated with idiosyncratic risk.

\subsection{Methodology}

Prior literature confirms that the $\beta$ measured by the CAPM can neither explain the excess market return nor represent the theoretical market risk. Therefore, three factors (i.e. market risk premium, size factor, and book-to-market factor) proposed by Fama and French $(1992,1993)$, and momentum-related factors introduced by Jegadeesh and Titman (1993) and Carhart (1997), are employed to reform the CAPM and are widely used in other subsequent studies. Following the above literature, this study adopts the four-factor model to measure firm-specific risk (i.e. idiosyncratic risk). The model is as follows:

$$
R_{i, t}-R_{f, t}=\alpha_{i}+\beta_{i, m}\left(R_{m, t}-R_{f, t}\right)+\beta_{i, S} S M B_{t}+\beta_{i, h} H M L_{t}+\beta_{i, u} U M D_{t}+\varepsilon_{i, t},
$$

where $R_{i t}$ is the stock return; $R_{f t}$ is the daily Treasury bill rate; $\beta_{i m}, \beta_{i s}, \beta_{i h}$, and $B_{i u}$ are the estimates of the four factors; $\varepsilon_{i t}$ is the random residual (i.e. the idiosyncratic risk or firm-specific risk).

This study explores the relationship between information transparency and idiosyncratic risk; however, prior study (e.g. Lin et al., 2014) suggests there is a possible endogeneity issue between information transparency and idiosyncratic risk. Hence, a simultaneous equation model is used in this study to address the endogeneity issue. The model is as follows:

$$
\begin{aligned}
& \text { IdioRisk }_{i, t}=f(I T, \text { Sales, } R O A, C F, L E V)_{i, t} ; \\
& I T_{i, t}=f(\text { IdioRisk, Sales, ROA,CF, LEV })_{i, t} ;
\end{aligned}
$$

where IdioRisk is the idiosyncratic risk, a proxy for idiosyncratic risk, measured by model (1); $I T$ is the information transparency; Sales is the operating revenue; ROA is the financial performance, measured as the ratio of operating income divided by total assets; $C F$ is the operating cash flow; $L E V$ is the debt ratio, measured as the ratio of total debt divided by total assets.

\section{Data}

In 2014 , it is the first time to massively and systematically assess the information disclosure level of top 200 companies. The assessment is conducted by the China Social Science Academic Press, and is published in the Annual Report on China's Companies' Public Transparency. The report is expected to be published at the end of each year, and the 2014 and 2015 reports have been so far released. Therefore, the Chinese corporate information transparency data is unique (top 200 companies) and rare (only two years).

There are five dimensions (98 elements in total) in the assessment system (see Table 1). The time dimension has 4 elements, including the release date of the annual report and CSR report. The content dimension has 59 elements, including mainly the environmental management, corporate governance and customer satisfaction. The channel dimension has 20 elements, including the availability of corporate information on the website, in the annual report and other channels. The form dimension has 10 elements, including the language of corporate reports, and whether each report has been audited. The quantity dimension has 5 elements, including 
the amount of corporate news on the website and in the CNKI database, and the amount of search results containing a company's full name and its abbreviation on the Baidu Search.

Table 1. The evaluation dimension of corporate information transparency

\begin{tabular}{lr}
\hline \hline Dimension & No. of element \\
\hline Time & 4 \\
Content & 59 \\
Channel & 20 \\
Form & 10 \\
Quantity & 5 \\
\hline Total & 98 \\
\hline \hline
\end{tabular}

Source: Blue Book of Companies' Public Transparency - Annual Report on China's Companies' Public Transparency (2014 2015) No.1 (p.6)

The score assigned to each dimension is different. For the time dimension, the score ranges between -0.5 and 1 . For the content dimension, 1 denotes "positive", and 0 otherwise. For the channel dimension, 1 denotes "positive", and 0 otherwise. For the form dimension, the score ranges between -0.2 and 1 . For the quantity dimension, the score ranges between 0.3 and 1 . The total score for the 98 items in five dimensions is 100 .

The initial sample size for the years 2014-2015 was 400. We then excluded 191 observations for non-listed firms and 28 observations for firms with incomplete financial data. Therefore, there was a final sample size of 181 observations. All the financial data were drawn from the CSMAR database.

\section{Empirical results}

Table 2 presents the empirical results of the simultaneous equation models. The results show that the higher the information transparency, the lower the idiosyncratic risk. That is, information transparency is significantly and negatively related to idiosyncratic risk, thus supporting our hypothesis. However, the results are not consistent with prior studies (e.g. Lin et al., 2014; Jin and Myers, 2006). This may be because prior studies usually examine the relationship from investment or finance perspectives, and thus the relationship is affected by those investment or finance variables. In addition, we find that Sales is positively related to IdioRisk and IT, whereas ROA and LEV are negatively associated with IdioRisk and IT, consistent with Lin et al. (2014).

Table 2. The results of the simultaneous equation models

\begin{tabular}{|c|c|c|}
\hline $\begin{array}{l}\text { Dependent variables } \\
\text { Independent variables }\end{array}$ & $\begin{array}{r}\text { Model (2) } \\
\text { IdioRisk } \\
\text { Coefficient }(t \text {-value })\end{array}$ & $\begin{array}{r}\text { Model (3) } \\
\text { IT } \\
\text { Coefficient (t-value) }\end{array}$ \\
\hline Intercept & $2.378(3.053) * * *$ & $-0.332(-2.898) * * *$ \\
\hline IT & $-1.197(-2.363)^{* *}$ & \\
\hline IdioRisk & & $-0.026(-2.363) * *$ \\
\hline Sales & $0.170(1.431)$ & $0.112(7.289)^{* * * *}$ \\
\hline ROA & $-4.497(-1.725)^{*}$ & $-0.190(-0.491)$ \\
\hline $\mathrm{FC}$ & $0.007(0.379)$ & $-0.003(-1.127)$ \\
\hline LEV & -0.000 & -0.000 \\
\hline Adjusted $\mathrm{R}^{2}$ & 0.031 & 0.272 \\
\hline Durbin-Watson & 0.939 & 1.103 \\
\hline Obs. & 181 & 181 \\
\hline
\end{tabular}

Notes: $* * * p<0.01 ; * * p<0.05 ; * p<0.1$ 


\subsection{Additional tests}

In order to show whether or not more transparent Chinese firms are able to raise capital at lower costs, and whether or not they suffer from changes in stock liquidity, we conduct two additional tests. The results are presented in Table 3 . We find that CEC is significantly and negatively associated with IT, which is consistent with prior studies (e.g. Hughes et al., 2007, Lambert et al., 2007). The results also show that the relationship between IdioRisk and StockLiqui is significantly positive, suggesting that firms with higher idiosyncratic risk have lower stock liquidity, which is similar to Heinle and Verrecchia (2012).

Table 3. The results of cost of capital and stock liquidity

\begin{tabular}{lrr}
\hline \hline $\begin{array}{l}\text { Dependent variables } \\
\text { Independent variables }\end{array}$ & $\begin{array}{c}\text { CEC }^{a} \\
\text { Coefficient }(t \text {-value })\end{array}$ & $\begin{array}{r}\text { StockLiqui } \\
\text { Coefficient }(t \text {-value) }\end{array}$ \\
\hline \hline Constant & $-0.068(-1.748)^{*}$ & $0.428(2.592)^{* * *}$ \\
IT & $-0.002(1.697)^{*}$ & $0.004(1.461)$ \\
IdioRisk & $-0.007(0.167)$ & $0.047(1.901)^{*}$ \\
Sales & $0.015(1.705)^{*}$ & $0.022(0.330)$ \\
ROA & $0.598(4.219)^{* * *}$ & $-1.845(-1.491)$ \\
FC & $-0.010(-1.359)$ & $-0.003(-0.071)$ \\
LEV & $-0.000(-0.086)$ & $-0.000(-0.437)$ \\
Adjusted $\mathrm{R}^{2}$ & 0.090 & 0.044 \\
$F$-value & $3.978^{* * *}$ & $2.412^{* *}$ \\
Obs. & 181 & 181 \\
\hline \hline
\end{tabular}

Notes: 1 . CEC is cost of capital, measured by the Easton (2004) model; StockLiqui is stock liquidity, measured by the Amihud (2002) model. 2. ***p $p<0.01 ; * * p<0.05 ; * p<0.1$.

\section{Conclusions}

This study focuses mainly on the relationship between information transparency and idiosyncratic risk. The empirical results indicate that the idiosyncratic risk reduces as a firm discloses more related financial and non-financial information. In specific, when considering investors' measurement of firm risks, firms shall improve their transparency in order to raise capital at lower costs; otherwise, they will suffer from decreases in stock liquidity (Hughes et al., 2007, Lambert et al., 2007, and Heinle and Verrecchia, 2012). In other words, overlooking the importance of information disclosure is detrimental to corporate development. Therefore, it is necessary to establish an effective evaluation system for information transparency, particularly for emerging economies. In addition, the results provide some evidence that there is an endogeneity problem between information transparency and idiosyncratic risk, which should be a concern in future similar studies; otherwise, the results would yield biased estimates.

The study makes the following specific contributions. First, prior literature (Liu and Anbumozhi, 2009; Jin and Myers, 2006) indicates that most firms' information disclosure is not transparent in China. The study explores the relationship between Chinese firms' information transparency and idiosyncratic risk, which provides a better understanding of the linkage between information disclosure and risk in China and other less transparent countries, such as India and Russian Federation (Jin and Myers, 2006). Second, the empirical results further find evidence of the endogeneity issue between information transparency and risk, which complements prior literature regarding the issue in emerging markets. 


\section{References}

Amihud, Y. (2002) Illiquidity and stock returns: cross-section and time-series effects, Journal of Financial Markets, 5(1), 31-56.

Bens, D.A. and Monahan, S.J. (2004) Disclosure quality and the excess value of diversification, Journal of Accounting Research, 42(4), 691-711.

Botosan, C. (1997) Disclosure level and the cost of equity capital, The Accounting Review, 72(3), $323-349$.

Bouslah, K.B.H., Kryzanowski, L. and M'Zali, B. (2016) Social performance and firm risk: impact of the financial crisis, Journal of Business Ethics, 1-27.

Bushman, R.M. and Smith, A.J. (2003) Transparency, financial accounting information, and corporate governance, Economic Policy Review,9(1), 65-87.

Carhart, M.M. (1997) On persistence in mutual fund performance, Journal of Finance, 52(1), 57-82.

Cremers, K.J. and Nair, V.B. (2005) Governance mechanisms and equity prices, Journal of Finance, 60(6), 2859-2894.

Durnev, A., Morck, R. and Yeung, B. (2004) Value-enhancing capital budgeting and firmspecific stock return variation, Journal of Finance, 59(1), 65-105.

Fama, E.F. and French, K.R. (1992) The cross-section of expected stock returns, Journal of Finance, 47(2), 427-465.

Fama, E. F. and K. R. French (1993) Common risk factors in the returns on stocks and bonds, Journal of Financial Economics, 33(1), 3-56.

Ferreira, M.A.and Laux, P.A. (2007) Corporate governance, idiosyncratic risk, and information flow, Journal of Finance, 62(2), 951-989.

Gompers, P.A., Ishii, J.L. and Metrick, A. (2003) Corporate governance and equity prices, The Quarterly Journal of Economics, 118(1), 107-155.

Gordon, L.A., Loeb, M.P. and Tseng, C.Y. (2009) Enterprise risk management and firm performance: a contingency perspective, Journal of Accounting and Public Policy,28, 301-327.

Heinle, M. and Verrecchia, R.E. (2012) Idiosyncratic risk, systematic risk, and firm welfare. Working paper, University of Pennsylvania.

Hoyt, R.E. and Liebenberg, A.P. (2011) The value of enterprise risk management, Journal of Risk and Insurance, 78(4), 795-822.

Hughes, J.S., Liu, J. and Liu, J. (2007) Information asymmetry, diversification, and cost of capital. Accounting Review, 82(3), 705-729.

Jegadeesh, N. and Titman, S. (1993) Returns to buying winners and selling losers: implications for stock market efficiency, Journal of Finance, 48(1), 65-91.

Jin, L. and Myers, S.C. (2006) R2 around the world: new theory and new tests, Journal of Financial Economics, 79(2), 257-292.

Lambert, R., Leuz, C. and Verrecchia, R. E. (2007) Accounting information, disclosure, and the cost of capital. Journal of Accounting Research, 45(2), 385-420.

Lee, D.W. and Liu, M.H. (2011) Does more information in stock price lead to greater or smaller idiosyncratic return volatility?, Journal of Banking and Finance, 35(6), 1563-1580.

Lee, J.S., Lai, K.L. and Huang, Y.K. (2015) Information transparency and idiosyncratic risk, Applied Economics Letters, 22(12), 934-937.

Lin, Y.M., Chao, C.F. and Liu, C.L. (2014) Transparency, idiosyncratic risk, and convertible bonds, European Journal of Finance, 20(1), 80-103.

Liu, X. and Anbumozhi, V. (2009) Determinant factors of corporate environmental information disclosure: an empirical study of Chinese listed companies, Journal of Cleaner Production, 17(6), 593-600. 
Morck, R., Yeung, B. and Yu, W. (2000) The information content of stock markets: why do emerging markets have synchronous price movements?, Journal of Financial Economics, 58(1), 215-260.

Smithson, C.and Simkins, B.J. (2005) Does risk management add value? a survey of the evidence, Journal of Applied Corporate Finance, 17(3), 8-17.

Wan, X. (2016) The contribution and impact of China economic growth on the world economy, China Daily, March 29, (in Chinese). 